\title{
Actualization of Ways to Introduce Russian Education into Digital Economy Realities
}

\author{
Slinkov A.M.* \\ Belgorod Institute of Education Development \\ Belgorod, Russia \\ e-mail: st121175@mail.ru \\ Vishnevskaya E.V. \\ Belgorod State National Research University \\ Belgorod, Russia \\ e -mail: Vishnevskaya@bsu.edu.ru \\ Nezhelchenko E.V. \\ Belgorod State National Research University \\ Belgorod, Russia \\ e-mail: nejelchenko@mail.ru
}

\begin{abstract}
The object of research is the process of transformation of economy, due to the development of digital technologies. The subject of research is the Russian education as a key social institution of formation and development of digital competence. The purpose is to study trends of modernization of Russian education in accordance with labor market requirements of digital economy. The article describes the evolution of the postindustrial housekeeper from the standpoint of the concepts of knowledge economy, information and digital economy. Based on a critical analysis of approaches to the definition of the digital economy formulated its author's definition. During the study, the following tasks were set and solved: The factors hindering the introduction of digital technologies in the activities of economic entities and population; assessed today Russian reality from the standpoint of the formation of the competitive opportunities of the digital economy; identify problem areas and contradictions inherent in the Russian education at all levels, prevent the formation and development of digital competences; It identified the main directions of transformation of the Russian education and the necessity of qualitative transformations of the educational process for the realization of the objectives set in the National Program "Digital Russian economy." The main results of the study are to identify priority areas of qualitative transformations of national education: substantive content and description of competencies of the digital economy for a variety of subject areas and spheres of professional activity; development of new educational programs and the modernization of the learning content of existing programs in accordance with the requirements of the emerging digital economy; development mechanisms of personal educational routes of students; substantial rethinking of educational technologies and e-learning and the creation of conditions for their effective use; formation in educational institutions of the corporate culture that can support and encourage innovative behavior of employees.
\end{abstract}

Keywords - knowledge economy, information economy, digital economy, digital technology, digital competence, the Russian education.

\author{
Slinkova O.K. \\ Belgorod State National Research University \\ Belgorod, Russia \\ e-mail: Slinkova@bsu.edu.ru \\ Yasenok S.N. \\ Belgorod State National Research University \\ Belgorod, Russia \\ e-mail: yasenok@ bsu.edu.ru
}

\author{
Zdorovets Yu.I. \\ Belgorod state Agricultural University named after V. Gorin \\ Belgorod, Russia \\ e-mail:zdorovec1980@mail.ru
}

\section{INTRODUCTION}

Digitalization is a key vector of development of the Russian economy. This provision is contained in a number of official documents. A national program of the digital economy is adopted and implemented. At the same time there are a number of problems and contradictions that complicate the tasks set out in this program. The absence in the Russian science a clear understanding of the nature and content of the digital economy is methodological problem. Among the applied nature of the problems it should be noted, first of all, lack of training in terms of ownership of digital competence. The solution to this problem requires the introduction of qualitative changes in the content of education at all levels.

\section{LITERATURE REVIEW AND METHODOLOGY}

The classical approach to the analysis of an evolutionary process in economy allocates three successive stages of its development:

- pre-industrial, characterized by the dominance of extractive industries and agriculture in the economy;

- industrialization phase in which priority was the manufacturing industry;

- post-industrial stage, which marked the final saturation, and a glut of the commodity markets and the active development of services.

The onset of the post-industrial era is associated with the middle of $\mathrm{XX}$ century. Over the past from this point on, the economy was subjected to numerous transformations that led to multiple attempts of researchers to differentiate the stages of development of post-industrial economy to a more precise identification. 
The first such attempt has been widely recognized, realized by F. Machlup. In his book "The production and dissemination of knowledge in the United States," published in 1962, he laid out the ideas that became the basis for the formation of the concept of knowledge economy [1]. The authors, who are supporters of this concept, consider the intellectual resources $[2,3]$ as a key factor in economic development.

Another concept of this kind is connected with the publication in 1977 of the book "information economy." Its author, M. Porat as a priority factor of economic development proposed to consider the information [4]. The concept of the information economy has gained great popularity and has many followers among the domestic and foreign researchers $[5,6]$.

In our opinion, the concept of the knowledge economy and the concept of the information economy are quite similar in nature. Information is usually any information that comprehends man. In this sense, the information does not exist outside the human mind. As it is known, this interpretation of information is a source of knowledge. Therefore, between knowledge and information, there is an intrinsic connection. On the other hand, the difference between these concepts lies in the fact that the concept of the information economy in addition to the intellectual component, the appropriate classification of the information, and focuses on the consideration of the technological component of the economy - the technical means of information, viewing them as an economic growth driver.

Among the modern concepts with the aim of identification of priorities in the economy it should be noted the concept of the digital economy. In Russia it deserves exclusive attention, as reflected in the National Program "Digital Russian economy." It is possible to assert with confidence that the issue of digitization is the main agenda of the Russian economy.

However, in the Russian society rather limited conception of the nature of the digital economy is still present. Moreover, in the scientific environment of the Russian public there is no generally accepted concept of digital economy, and sometimes the concept of the digital economy and the information is treated as identical. The determination of digital economy, embedded in a national program, it is not enough for us a clear and logical: "digital economy is the economic activity, a key factor of production which is the data in digital form, and contributes to the development of the information space, taking into account the needs of citizens and society in obtaining qualitative and reliable information, the development of the national information infrastructure,

It is necessary to note that there is no unity on this issue in the foreign scientific literature. The analysis of foreign researchers approaches to determining the nature of the digital economy showed great variability, which is in the field of two opposing trends. The first deals with the most generalized form of reflection of the essence of the digital economy. An example of this approach is the following definition: "complex structure, consisting of several levels / layers interconnected virtually infinite and constantly growing number of nodes" [11].
The second trend, viewed in the construction of the definitions of the digital economy, is to specify and transfer of its basic components, such as: "Digital economy is characterized by reliance on intangible assets, the massive use of the data, the widespread introduction of multilateral business models and the difficulty in determining the jurisdiction in which the creation of value " [12]

The following definition of digital economy seems as the most suitable: the system of economic relations, based on the networking of people, organizations, technical devices, databases and processes are formed by use of the Internet and mobile technologies.

\section{RESULTS AND DISCUSSION}

The realization of the program of digitization of the economy requires fundamentally new competences that determine the willingness and ability of society to use new technologies in professional activity, as well as in everyday life. It will also have to overcome quite common in the minds of Russian concerns about the negative effects of the introduction of digital technologies in life. For example, a survey of 3-4 December 2019 showed that more than a third of Russians (35\%) did not approve of the introduction of electronic work books [8].

The biggest fear of the Russians in the introduction of digital technology cause:

- questions of preservation of digital data due to possible cyber attacks and viruses;

- issues of data privacy and individual rights;

- questions the disappearance of many traditional occupations in connection with the replacement of their automated systems. This fear has a real basis: According to specialists, the current level of development of digital technology allows automating at least $30 \%$ of job functions within an existing professional field [13], and the proportion of new activities as early as in 2027 will reach $27 \%$ [15].

Nevertheless, Russia has quite a favorable situation for the formation of a competitive digital economy. According to the World Economic Forum, Russia ranks 25th among 140 countries on the index "The penetration of information and communication technologies "(see Table 01).

TABLE I. RATING OF RUSSIAN FEDERATION "THE PENETRATION OF INFORMATION AND COMMUNICATION TECHNOLOGIES" IN 2018CITY*

\begin{tabular}{|l|c|}
\hline \multicolumn{1}{|c|}{ Indicators } & A place \\
\hline The number of mobile phone subscribers per 100 population & eleven \\
\hline $\begin{array}{l}\text { The number of subscribers of mobile broadband access to the } \\
\text { Internet per 100 inhabitants of the population }\end{array}$ & 51 \\
\hline $\begin{array}{l}\text { The number of subscribers of fixed broadband access to the } \\
\text { Internet per 100 inhabitants of the population }\end{array}$ & 46 \\
\hline $\begin{array}{l}\text { The number of connections to the Internet via fiber-optic } \\
\text { network to 100 people }\end{array}$ & 12 \\
\hline $\begin{array}{l}\text { The share of the population using the Internet, in the general } \\
\text { population }\end{array}$ & 49 \\
\hline \begin{tabular}{l} 
ICT index \\
\hline
\end{tabular} & 25 \\
\hline
\end{tabular}


In all developed countries the process of digitization of the economy accompanied by significant measures of state support. And Russia is not an exception. On the implementation of the "digital economy of the Russian Federation" program in the 2019-2021 biennium. It provided 410 billion rubles from the federal budget and about 535 billion rubles from extra-budgetary sources support measures are provided in all stages of the life cycle of digital technology: the implementation of basic and applied research, the implementation of experimental development, pilot and mass production, formation of demand for digital solutions and their practical use. We note with particular importance to stimulate demand or digital technology. According to experts, "There is a demand on the part of the economy of innovation and innovative products," creates the necessary preconditions of innovative development [18].

Ultimately, it is the main demand and a measure of the competitiveness of any product on the market, including digital. Here it should be recognized that due to, inter alia, measures of state support, there is the presence of a sufficiently high demand for digital technology in the field of implementation of public administration and large business functions. As for small and medium-sized businesses, it shows a very low level of investment activity aimed at business process digitization. As for the demand for digital solutions from the population, it is mainly inherent in young people, and not always is solvent.

The improvement of the competitiveness of Russia in the sphere of the use of digital technologies poses entirely new challenges for the Russian education at all levels. It should be noted here that today's young people using digital technology almost since birth, has great potential for the development of digital competences [20]. Unfortunately, this can not be said in respect of a substantial proportion of teachers and teachers of secondary and higher educational institutions experiencing considerable difficulties in developing new technologies.

As a result, there is a problem of interaction between "digital" students and "non-numeric" teachers. Representatives of the $\mathrm{Z}$ generation, according to the generations theory W. Strauss and N. Howe, often identified as "digital people" Exhibit significant activity in the sphere of Internet, blogging, social networks, mobile applications and games, and not simply as a process of users, but also as its creators. On the other hand, there is a reluctance to leave the teachers honored "comfort zone" and to develop their competence in the field of digital technologies. Therefore, a teacher and a student often do not have a common language because there are no skills in the use of modern technologies in the appointed and extracurricular activities to achieve increased efficiency in training, appropriate requirements of reality, becomes virtually impossible.

Describing the Russian society, it should be noted that there is a big gap in learning the skills of using digital technology in various population groups. At the same time, according to a study conducted by the Institute for Strategic Studies and Economics of Knowledge of the Higher School of Economics, even among individuals with higher qualifications (candidates and doctors of sciences) share holding modern digital was not too high technologies. For example, large data analysis technologies owned by $29.9 \%$ of respondents, while $42.2 \%$ are not even aware of such a term. Technology text mining uses in its activities $21 \%$ of respondents, while $63.4 \%$ of respondents do not have even elementary concepts of this technology [14].

Substantial restructuring of the entire national education system is required. In fact, modern schools lose their monopoly in the provision of educational services, as well as in educating the younger generation. The possibility of obtaining any information from the Internet, the emergence of open access numerous online courses greatly devalues the role of a teacher and a teacher as the main source of knowledge. It is obvious that the teachers and especially teachers of secondary and higher education institutions need to change the role of the translator knowledge of the role of the conductor in the complex world of ever-changing information.

National program "Russian Digital Economy" puts the very ambitious goals for the Russian education system (Table 2).

TABLE II. TARGETS OF THE PROGRAM*

\begin{tabular}{|l|c|c|c|}
\hline \multicolumn{1}{|c|}{ Indicators } & $\mathbf{2 0 2 0}$ & $\mathbf{2 0 2 1}$ & $\mathbf{2 0 2 4}$ \\
\hline $\begin{array}{l}\text { Ratio state attestation graduates using digital } \\
\text { information technology, } \%\end{array}$ & 15 & 40 & 100 \\
\hline $\begin{array}{l}\text { Number of graduates of the vocational education } \\
\text { system with the basic competencies of the digital } \\
\text { economy, thous. People. in year }\end{array}$ & 300 & - & 800 \\
\hline $\begin{array}{l}\text { The number of graduates of higher professional } \\
\text { education of IT-specialties thousand. People. in } \\
\text { year }\end{array}$ & 80 & - & 120 \\
\hline $\begin{array}{l}\text { The proportion of the teaching staff of educational } \\
\text { institutions, requalification training for } \\
\text { competencies of the digital economy, } \%\end{array}$ & - & 100 & - \\
\hline $\begin{array}{l}\text { The number of specialists, retrained as part of } \\
\text { additional education, th. People. }\end{array}$ & 500 & - & 1000 \\
\hline $\begin{array}{l}\text { The proportion of citizens to improve literacy in } \\
\text { the field of information security, media } \\
\text { consumption and use of Internet services, } \%\end{array}$ & 20 & 25 & 50 \\
\hline
\end{tabular}

The figures presented in Table 2 give an idea of the magnitude of the problems facing education. However, the complexity of the problems to be solved, not even determined by these quantitative indicators. The main thing - it is the qualitative transformation, which has to undergo the educational process itself. [19] Among the most significant organizational and methodological problems to be solved to the Russian education, we include the following.

Firstly, we need informative content and description of competencies of digital economy for all levels of education, both universal and correlated with a variety of subject areas and spheres of professional activity. It is necessary to use a competence approach in the national educational system in general, consistent with the concept of digital economy, but the very system of competences must flexibly evolve in line with technological changes in their respective fields.

Secondly, it requires the development of new educational programs and continuous upgrading of the educational content 
of existing programs in accordance with the evolving labor market needs of the digital economy.

Third, it is necessary to develop mechanisms of formation and practical realization of the personal educational routes of students. Today, the variability of study in Russian universities is provided by the inclusion in the curricula of disciplines at the choice of students and many of them have implemented formal, without real consideration of the wishes of the students. The program will provide for the transfer of $100 \%$ of students on individual learning paths for digital competencies already in 2024 [7].

Fourth, it is necessary to rethink the content of educational technology and e-learning, including through networking of educational institutions and create the conditions for their effective use. Today, during the assessment of the progressivity the educational technologies are taken into account: technical rather than substantive component. As a result of this approach the very essence of education to the forefront not the goal but a means is emasculated. For example, distance education gaining popularity in the Russian universities is often reduced to a simple recording of lectures, read in traditional form, with a video camera. Or, for example, the introduction of electronic textbooks in school requires a complete overhaul of the educational process when a student masters the material at home and in school to acquire the necessary explanations,

Finally, the baseline implementation tasks are the ability of workers to the use of innovations in the learning process (the question of skill) and willingness of educational organizations and their employees to innovate, and secondly. The first one (the development of digital competence) is the task of training and retraining. The second one is the question of motivating employees and creating an organizational culture that can support and encourage innovative behavior of employees [16, 17]. It should be noted in this connection that exists in the Russian educational institutions corporate culture rife with bureaucratic elements that substantially limits any creative and innovative manifestations in the behavior of employees.

\section{CONCLUSION}

The study revealed a number of urgent problems of modern Russia, are entering the era of digitalization:

- the need for ongoing monitoring of issues arising from the digital transformation of the economy, especially in the field of employment and labor market demand for specialists with the development of digital competences;

- the need for public support for digitization of processes not only at the level of implementation of the functions of government, but also stimulate demand for digital solutions a real business and the public;

- the need for a large educational work to remove psychological barriers to the introduction of digital technology and increasing digital literacy;

- the need for significant adjustment of the Russian education system at all levels, involving, above all, qualitative transformation of the learning process.

\section{References}

[1] F. Machlup, The Production and Distribution of Knowledge in the United States. Princeton: Princeton Univer. Press, 1962, 360 p.

[2] V.V. Glukhov, Knowledge economy. St. Petersburg: Peter, 2003, 286 p.

[3] J. Houghton, P. Sheehan, A Primer my. Melbourne: Victoria Univer. Centre for Strategic Econ. Studies, 2000, 186 p.

[4] M. Porat, The information economy. Washington, 1977, $286 \mathrm{p}$.

[5] J.K. Gelbreyg, New Industrial State. Moscow: AST, 2004, 330 p.

[6] S.A. Dyatlov, Subject and method of information economics theory, In: Economic theory at the threshold of the XXI century. Moscow: Yurist, 1998, $256 \mathrm{p}$.

[7] Program "The digital economy of the Russian Federation", 2017. Retrieved from: http: static.government.ru (Accessed 30.01.2020).

[8] One third of Russians are opposed to e-books, 2019. Retrieved from: https://www.gazeta.ru/business/2019/12/05/12849374.shtml (Accessed 30.01.2020).

[9] WEF. The Global Competitiveness Report. K. Schwab (ed.)., 2018, pp. 484-485. Retrieved from: http://www3.weforum.org/docs/ GCR2018/05FullReport/TheGlobalCompetitivenessReport2018.pdf (Accessed 30.01.2020).

[10] Australian Government. Australia's Digital Economy: Future Directions 2009. Retrieved from: https://www.oaic.gov.au/images/documents/ migrated/migrated/sub_broadband_digital_economy.pdf> (Accessed 17.01.2020).

[11] European Parliament, 2015. Challenges for Competition Policy in a Digitalised Economy. Retrieved from: http://www.europarl.europa.eu/ RegData/etudes/STUD/2015/542235/IPOL_STU\%282015\%29542235_ EN.pdf (Accessed 13.01.2020).

[12] OECD. "Addressing the Tax Challenges of the Digital Economy", Action 1 - 2015 Final Report. Paris: OECD Publishing. 2015

[13] McKinsey. "A Future That Works: Automation, Employment and Productivity", 2017. Retrieved from: https://www.mckinsey.com/ / media/McKinsey/Featured\%20Insights/Digital\%20Disruption/Harnessin g\%20automation $\% 20$ for $\% 20 \mathrm{a} \% 20$ future $\% 20$ that $\% 20$ works/MGI-Afuture-that-works_Executive-summary. ashx (Accessed 10.01.2020).

[14] What is the digital economy? Trends, competence measurement, Report of the HSE. Moscow: Home Higher School of Economics, 2019, 82 p.

[15] Mass uniqueness. A global challenge in the fight for talent in 2019. Retrieved from: file: /// C: / Users / User / Desktop /\% D0\% 9C\% D0\% $\mathrm{B} 0 \% \mathrm{D} 1 \% 81 \% \mathrm{D} 1 \%$ 81\% D0\% BE\% D0\% B2\% D0\% B0\% D1\% 8F\% $20 \%$ D1 \% $83 \%$ D0\% BD\% D0\% B8\% D0\% BA\% D0\% B0\% D0\% BB\% D1\% 8C\% D0\% BD\% D0\% BE\% D1\% $81 \%$ D1\% 82\% D1\% 8C.pdf (Accessed 10.01.2020).

[16] T.V. Sabetova, M.V. Ponomarenko, "Analysis and ranging of the factors of formation and development of innovative behaviour in organizations", Proc. of the Voronezh State Univer. of Engineer. Technol., vol. 80, no. 3, pp. 478-488, 2018.

[17] E.G. Grudistova, "Methodical bases of management of organizational culture", Probl. of soc. and econ. development of Siberia, vol. 2, no. 2, pp. 9-20, 2010.

[18] M.S. Asmolova, S.V. Dedov, "The algorithm to ensure and implemen the strategy of the effective management of innovation processes", Proc. of the Voronezh State Univer. of Engineer. Technol., vol. 80, no. 4, pp. 436-440, 2018.

[19] A.M. Patrusova, O.K. Slinkova, "Application of the principles of quality management in educational institutions of higher professional education", Proc. of Bratsk State Univer., Ser. Econ. and Manag., vol. 1, pp. 277-284, 2013.

[20] E.G. Grudistova, D.A. Pastukhova, A.M. Slinkov, O.K. Slinkova T.N. Melnikov, "Study of self-actualization needs of Russian students as a factor of competitiveness in the labor market", Espacios, vol. 40, no. 26, 2019. 